\title{
A Brief Review of $\kappa$-Carbide in Fe-Mn-Al-C Model Alloys
}

\author{
Jae Bok Seol*
}

\author{
National Institute for Nanomaterials Technology (NINT), POSTECH, Pohang 37673, Korea
}

*Correspondence to:

Seol JB,

(iD) http://orcid.org/0000-0001-9143-4274

Tel: $+82-54-279-0220$

Fax: +82-54-279-0249

E-mail: jb_seol@postech.ac.kr

Received December 21, 2018

Revised December 26, 2018

Accepted December 27, 2018
The multiple length scale analysis of previously designed Fe-Mn-Al-C based low-density model alloys reveals the difference in ordered $\kappa$-carbide, $(\mathrm{Fe}, \mathrm{Mn})_{3} \mathrm{AlC}_{\mathrm{x}}$, between $\mathrm{Fe}-25 \mathrm{Mn}$ 16Al-5.2C (at\%) alloy and Fe-3Mn-10Al-1.2C (at\%) alloy. For the former alloy composition consisting of fully austenite grains, $\kappa$-carbide showed majorly cuboidal and minorly pancake morphology and its chemical composition was not changed through aging for $24 \mathrm{~h}$ and 168 $\mathrm{h}$ at $600^{\circ} \mathrm{C}$. Meanwhile, for the isothermally annealed ferritic alloy system for $1 \mathrm{hr}$ at 500 and $600^{\circ} \mathrm{C}$, the dramatic change in the chemical composition of needle-shape $\kappa$-carbide, $(\mathrm{Fe}, \mathrm{Mn})_{3}(\mathrm{Fe}, \mathrm{Al}) \mathrm{C}_{\mathrm{x}}$, was found. Here we address that the compositional fluctuations in the vicinity of the carbides are significantly controlled by abutting phase, either austenite or ferrite. Namely, the cooperative ordering of carbon and $\mathrm{Al}$ is an important factor contributing to carbide formation in the high-Mn and high-Al alloyed austenitic steel, while the carbon and $\mathrm{Mn}$ for the low-Mn and high $\mathrm{Al}$ alloyed ferritic steel.

Key Words: Low-density steels, High manganese and aluminum alloyed steels, Ordered carbides, Transmission electron microscopy, Atom probe tomography

\section{INTRODUCTION}

Recently, a novel class of steels with varying $\mathrm{Al}$ contents has received great attention for structural and automotive engineering applications (Springer \& Raabe, 2012; Seol et al., 2012; Seol et al., 2013; Gutierrez-Urrutia \& Raabe, 2013; Raabe et al., 2014; Choi et al., 2010). In particular, high-Al containing Fe-Mn-Al-C alloys offer a superior combination of low mass density, improved corrosion resistance, high strength and excellent ductility in comparison to those of transformationinduced plasticity (TRIP) or twinning induced plasticity (TWIP) steels (Seol et al., 2013; Gutierrez-Urrutia \& Raabe, 2013; Raabe et al., 2014). High amounts of $\mathrm{Al}$ are reported to promote the precipitation of ordered $\kappa-(\mathrm{Fe}, \mathrm{Mn})_{3} \mathrm{AlC}_{\mathrm{x}}$ with perovskite-type structure, which can control the overall mechanical properties of the steels. Pronounced manufacture of high-Al advanced steels with superior mechanical properties has been achieved via varying with the chemical composition of materials, especially controlling $\mathrm{Mn}$ and $\mathrm{C}$ contents. Alloying of $\mathrm{Fe}_{3} \mathrm{AlC}_{\mathrm{x}}$ with $\mathrm{Mn}$ and $\mathrm{C}$ produces a structural change in the characteristics of carbide precipitation from $\mathrm{BCC}$ based $\mathrm{DO}_{3}$ structure, $\mathrm{Fe}_{3} \mathrm{Al}$, to $\mathrm{FCC}$ based perovskite-type L' $1_{2}$ structure, $(\mathrm{Fe}, \mathrm{Mn})_{3} \mathrm{AlC}_{\mathrm{x}}$ (Springer \& Raabe, 2012; Seol et al., 2013; Raabe et al., 2014; Choi et al., 2010). Such high-Al bearing lightweight steels can be classified into two main steel grades, namely, the ferritic Fe-Mn-Al-C alloys of low-Mn contents between 3 and 8 wt.\% and the austenitic alloys containing high-Mn contents between 18 and $30 \mathrm{wt} . \%$. In recent years, we reported that lamellar-type $\kappa$-carbides were formed in a ferritic Fe-3.0Mn-3.0Al-0.3C (wt.\%) alloy as a result of a eutectoid reaction associated with nucleation and growth during isothermal annealing between $500^{\circ} \mathrm{C}$ and $600^{\circ} \mathrm{C}$ (Raabe et al., 2014). For austenitic lightweight alloys with high-Mn content, the $\kappa$-particles with rectangular shape were reported to precipitate out mainly from the austenitic matrix via spinodal decomposition during aging between $500^{\circ} \mathrm{C}$ and $600^{\circ} \mathrm{C}$ (Seol et al., 2013; Gutierrez-Urrutia \& Raabe, 2013; Raabe et al., 2014; Choi et al., 2010). The strong effects of $\mathrm{Al}$ on the precipitation in Fe$30.5 \mathrm{Mn}-8.0 \mathrm{Al}-1.2 \mathrm{C}$ (wt.\%) alloys, allows the steel grade to

(a) This is an open-access article distributed under the terms of the Creative Commons Attribution Non-Commercial License (http://creativecommons.org/licenses/by-nc/4.0) which permits unrestricted noncommercial use, distribution, and reproduction in any medium, provided the original work is properly cited.

Copyrights (C) 2018 by Korean Society of Microscopy 
be considered as promising lightweight structural materials exhibiting a superior strength-ductility-density balance (yield strength: $\sim 990 \mathrm{MPa}$; ultimate tensile strength: 0.9 1.2 GPa; uniform elongation: 37 65\%; 5 9 $\mathrm{g} \mathrm{cm}^{-3}$ ) (Gutierrez-Urrutia \& Raabe, 2013; Raabe et al., 2014). However, an atomistic understanding of $\kappa$-carbide precipitates formed in austenitic alloys is still unclear from an experimental point of view. In addition, it has been a lack of comparative studies on the morphology, chemical composition, and formation of the carbides existing in the ferritic steels to the austenitic steels.

The present study aims at revealing the detailed aspects of $\kappa$-carbide in both thermally aged austenitic steels and isothermally annealed ferritic steels from an atomic-scale regime, such as morphology, crystalline structure, chemical composition, and elemental partitioning using transmission microscopy and atom probe tomography (Bang et al., 2015; Seol et al., 2013).

\section{EXPERIMENTAL PROCEDURE}

The austenitic alloy studied in the work contains $25.0 \mathrm{Mn}$, $15.8 \mathrm{Al}$, and $5.6 \mathrm{C}$ in at\%. Details of the sample processing were reported elsewhere (Raabe et al., 2014). This alloy was solution-treated at $1100^{\circ} \mathrm{C}$ for $2 \mathrm{~h}$ followed by water quenching. Subsequently, aging were carried out at $600^{\circ} \mathrm{C}$ for $24 \mathrm{~h}$ and $168 \mathrm{~h}$. Meanwhile, a ferritic-based alloy with a composition of 3.2 Mn, 10.0 Al, and 1.2 C in at\%. Details of the alloy preparation and the thermo-mechanical processing have been published elsewhere (Seol et al., 2013). Twostep isothermal annealing was applied to the cold-rolled steels, namely, intercritical annealing at $900^{\circ} \mathrm{C}$ for $30 \mathrm{~min}$ in protective Ar atmosphere followed by isothermal annealing at $500^{\circ} \mathrm{C}$ or $600^{\circ} \mathrm{C}$ for $60 \mathrm{~min}$ and water quenching. The cooling rate from $900^{\circ} \mathrm{C}$ to the holding temperature was $\sim 100 \mathrm{~K} / \mathrm{s}$.

Microstructure characterization was done by TEM (JEM
2010F) and selected area diffraction pattern (SADP). The TEM samples were prepared by electrochemical polishing. The lattice parameters of the $\kappa$-phase and the austenite were determined by high resolution TEM (HRTEM). The chemical composition of the $\kappa$-phase was determined by energy dispersive spectroscopy (EDS) on a Cs-corrected STEM (JEM $2100 \mathrm{~F}$ ) and atom probe tomography (APT).

\section{RESULTS AND DISCUSSION}

A representative TEM dark-field image of high-Mn and high$\mathrm{Al}$ containing steel after annealing is shown in Fig. 1A. It reveals the microstructure consisting of an austenitic matrix and secondary-phase particles. Analysis of selected area diffraction patterns along the [001] zone axis shows the presence of $\{100\}$ and $\{010\}$ superlattice reflections. This indicates that the particles are ordered $\kappa$-carbides of $L^{\prime} 1_{2}$-type structure with a cube/cube orientation with the austenite matrix. TEM images confirm that at the present annealing conditions, the $\kappa$-carbides consist of cuboid $(20 \times 17 \mathrm{~nm})$ and plate-type $(8 \times 18 \mathrm{~nm})$ rectangular shaped particles. The $\kappa$-carbides have been commonly observed in Fe-Mn-Al-C steels with high Al (between 6 and 11 wt.\%) and C (between 0.2 and 1.8 wt.\%) contents. It has been reported a change in the morphology of the $\kappa$-carbides with annealing time which is associated to the loss of particle coherency upon coarsening. Higher particle coherency has been observed in austenitic Fe-Mn-Al-C alloys (Gutierrez-Urrutia \& Raabe, 2013; Choi et al., 2010) than in ferritic systems (Seol et al., 2013). Accordingly, different morphological evolution upon annealing has been reported. For instance, for the ferritic lightweight Fe-3.0Mn-6.0Al-0.3C (wt.\%) alloys after isothermal transformation, an increase in the annealing temperature from $500^{\circ} \mathrm{C}$ to $600^{\circ} \mathrm{C}$ allows the shape of the $\kappa$-phase to change from extremely elongated rodtype to cylindrical-type as a result of higher $\delta$ value between
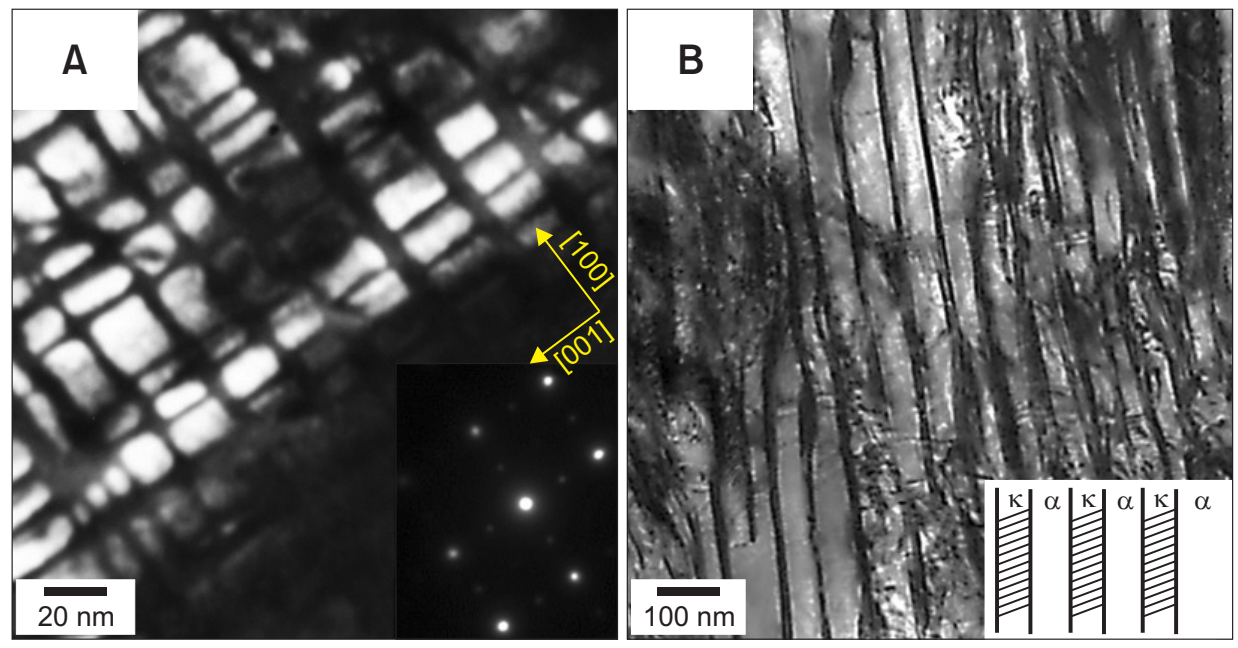

Fig. 1. TEM micrographs of $\kappa$-carbides, obtained from (A) high-Mn high-Al austenitic steels (Gutierrez-Urrutia \& Raabe, 2013; Raabe et al., 2014) and from (B) low-Mn high-Al ferritic steels (Seol et al., 2013). 


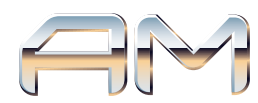

A
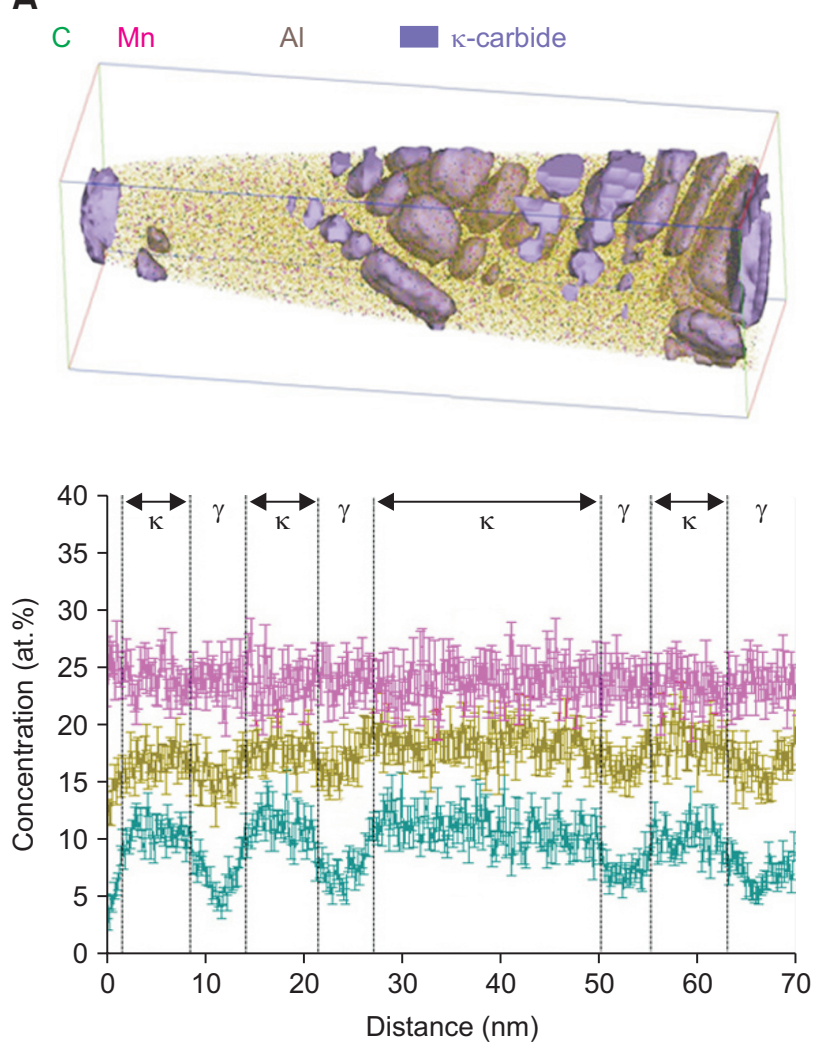

B
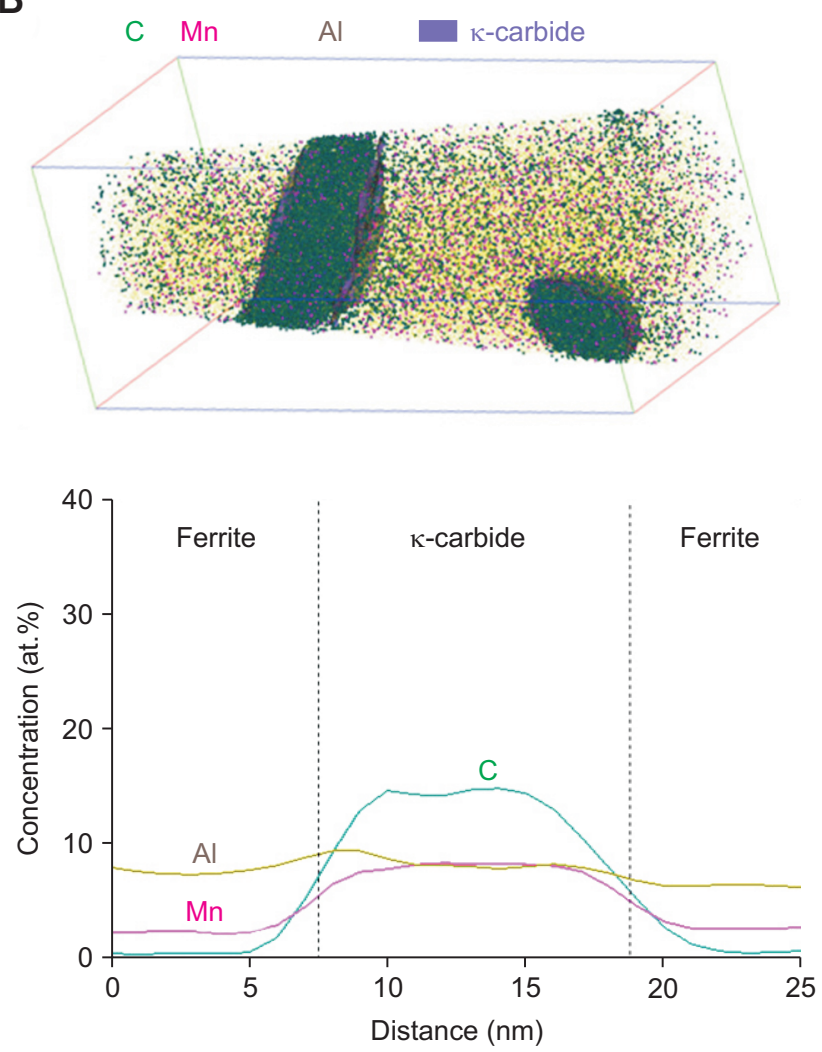

Fig. 2. Atom maps of $\mathrm{C}, \mathrm{Mn}$ and $\mathrm{Al}$, and corresponding concentration profiles across matrix-carbide interfaces, taken from (A) high-Mn high- $\mathrm{Al}$ austenitic steels (Raabe et al., 2014) and (B) low-Mn high-Al ferritic steels (Seol et al., 2013).

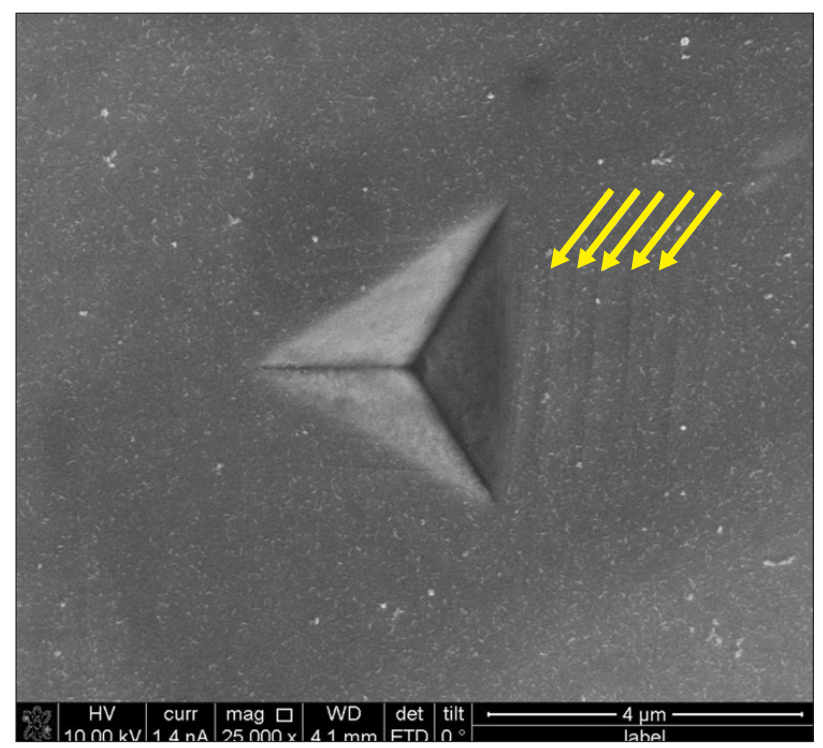

Fig. 3. SEM image of slip formation during nano-indentation testing.

ferritic grains and $\kappa$-phase (Seol et al., 2013). In contrast, a cuboidal to rectangular/plated-shape morphological evolution has been commonly reported in austenitic Fe-Mn-Al-C alloys
(Gutierrez-Urrutia \& Raabe, 2013; Raabe et al., 2014; Choi et al., 2010).

Fig. 1B shows a representative TEM micrograph and corresponding diffraction pattern, taken from the intercritically annealed and isothermally holding steel. The final microstructure is composed of a polygonal ferritic matrix $\left(\alpha_{\mathrm{p}}\right)$ and the lamellae formed along the prior $\gamma$ grain boundaries. In the lamellar structure, there are three other phases, such as fine ferrite, $\kappa$-carbide, and retained austenite $\left(\gamma_{\mathrm{R}}\right)$. Hence, the $\gamma$ phase is partially decomposed into ferrite and needle-like $\kappa$-carbide $\left(\gamma \rightarrow \kappa+\alpha_{2}+\gamma_{R}\right)$. Details of the interpretations been published elsewhere (Seol et al., 2013).

In recent years, we confirms that the chemical concentration of $\kappa$-carbide particles, $\mathrm{Fe}_{2} \mathrm{MnAlC}_{0.5}$, nearly is closed to that of $\kappa$-particles formed in the austenitic steels after aged for $96 \mathrm{~h}$ at $600^{\circ} \mathrm{C}$ as shown in Fig. 2A. Even longer aging time of $170 \mathrm{~h}$, we do not observe pronounced partitioning of $\mathrm{Mn}$ to $\kappa$-carbides. To date, the stoichiometric structure of $\kappa$-carbide $\mathrm{Fe}_{3} \mathrm{AlC}$ has not been reported experimentally (Seol et al., 2013; Raabe et al., 2014). Instead, the exact stoichiometry of the carbide has been only addressed using theoretical approaches (Chao et al., 1993; Connétable \& Maugis, 2008). For instance, four different stoichiometric structures of $\kappa$-carbide have been 
theoretically described varying with the Mn content, namely, $\mathrm{Fe}_{3} \mathrm{AlC}, \mathrm{Fe}_{2} \mathrm{MnAlC}, \mathrm{FeMn}{ }_{2} \mathrm{AlC}$, and $(\mathrm{Fe}, \mathrm{Mn})_{3} \mathrm{AlC}$. Note that the crystalline structures of $\mathrm{Fe}_{2} \mathrm{MnAlC}$ and $\mathrm{FeMn}_{2} \mathrm{AlC}$ exhibit tetragonal symmetry, and hence have two different lattice constants along the $\mathrm{x}$-axis and $\mathrm{z}$-axis of the tetragonal structure. Using density functional theory (DFT) calculations, Noh and Kim (2011) reported that the formation energy $(113 \mathrm{~kJ} / \mathrm{mol})$ of $\kappa-\mathrm{Fe}_{2} \mathrm{MnAlC}$ at absolute zero temperature is higher than that of $\kappa-(\mathrm{Fe}, \mathrm{Mn})_{3} \mathrm{AlC}(90 \mathrm{~kJ} / \mathrm{mol})$. This positively larger value of $\kappa-\mathrm{Fe}_{2} \mathrm{MnAlC}$ than $\kappa-(\mathrm{Fe}, \mathrm{Mn})_{3} \mathrm{AlC}$ means an enhanced energetic stability of $\kappa-\mathrm{Fe}_{2} \mathrm{MnAlC}$. On the other hand, the incomplete filling of $\mathrm{C}$ atoms in the ordered $\kappa$-carbide structure has been conducted by CALPHAD type thermodynamic descriptions. Based on the above-mentioned theoretical approaches and our experimental findings, we propose that the $\kappa$-carbides formed in our steels after aging at $600^{\circ} \mathrm{C}$ is very stable tetragonal structured $\mathrm{Fe}_{2} \mathrm{MnAl}(\mathrm{C}, \mathrm{Va})$, even after longer aging time.

As following APT measurements shown in Fig. 2B, we suggest under-stoichiometry of the $\kappa$-carbide with respect to $\mathrm{C}$ at the body center sites and partial replacement of $\mathrm{Al}$ by $\mathrm{Fe}$ or $\mathrm{Mn}$ in the corner positions in its fcc-based unit cell. Thus, the composition of the $\kappa$-phase can be expressed as $(\mathrm{Fe}, \mathrm{Mn})_{3}(\mathrm{Fe}, \mathrm{Al}) \mathrm{C}_{\mathrm{x}}$. Details of the interpretations were reported elsewhere (Seol et al., 2013). Therefore, we conclude that during $\gamma$ decomposition into $\kappa$ and $\alpha_{2}$, both product phases are competing sites for Al. The solute concentrations inside $\kappa$-carbide as determined by APT mass spectrum analyses amount to $11.2 \pm 1.0$ at. $\%$ C, $19.8 \pm 1.2$ at. $\% \mathrm{Al}$, and $24.7 \pm 0.9$ at. $\% \mathrm{Mn}$. Inside nano-channels between particles, $24.6 \pm 2.1$ at. $\% \mathrm{Mn}, 12.5 \pm 1.9$ at. $\% \mathrm{Al}$, and $2.2 \pm 1.3$ at.\% carbon are measured in average. It is important to note that the $\mathrm{C}$ concentrations in the nano-channels are about two times lower than those of SPR zones (4.8 \pm 0.8 at.\%). C inside the channels is relatively depleted, which might lead to locally a decrease in the stacking fault energy of the present alloy. This would give a strong hint for understanding interaction between dislocations and nanoparticles occurring during deformation (Gutierrez-Urrutia \& Raabe, 2013; GutierrezUrrutia \& Raabe, 2012). Following our APT results, it is plausible that the C-depleted channels between particles play a substantial role in the development of planar dislocation substructure or dislocation cross-slip during deformation. Details of $a b$ initio in our system and the stability of nanoparticles are addressed well in the literature (Yao et al., 2016). Fig. 3 shows SEM image of planar slip bands formed during nano-indentation testing. Details of deformed microstructure are also addressed in the literature (Gutierrez-Urrutia \& Raabe, 2013; Gutierrez-Urrutia \& Raabe, 2012).

\section{SUMMARY}

Both the stability of $\gamma$ phase at elevated temperatures and the thermal-processed approaches play a substantial role in the morphology and the chemical composition of $\kappa$-carbide particles. In the austenitic steels, $\kappa$-carbide particles have a mixed morphology of cuboidal and lenticular shape, whereas needle-like shape of a high aspect ratio for the ferritic steels. APT results revealed the chemical composition of the corresponding nanoparticles, thus enabling us to understand the cooperative partitioning of solutes in the vicinity of the $\kappa$-phases. The aging of austenitic lightweight steels leads to cooperative partitioning of $\mathrm{C}$ and $\mathrm{Al}$ atoms to ordered $\kappa$-carbide particles, mainly contributing to the formation of $\kappa$-carbide in the austenite matrix. As a result, fully austenitic microstructure consists of precipitate-free zones and precipitate regions including $\mathrm{C}$-depleted nano-channels between particles. Furthermore, we measured a $\kappa$-carbide composition that suggests a defected-rich state of $\kappa$-carbide containing vacancies.

\section{CONFLICT OF INTEREST}

No potential conflict of interest relevant to this article was reported.

\section{ACKNOWLEDGMENTS}

This research was supported by Basic Science Research Program through NRF funded by the Ministry of Science and ICT (2018R1C1B6008585).

\section{REFERENCES}

Bang C W, Seol J B, Yang Y S, and Park C G (2015) Atomically resolved cementite dissolution governed by the strain state in pearlite steel wires. Scripta Mater. 108, 151-155.

Chao C Y, Hwang C N, and Liu T F (1993) GRAIN-BOUNDARY PRECIPITATION IN AN FE-7.8 AL-31.7 MN-0.54 C ALLOY. Scripta Metall. Mater. 28, 109-114.
Choi K, Seo C H, Lee H, Kim S K, Kwak J H, Chin K G, Park K T, and Kim N J (2010) Effect of aging on the microstructure and deformation behavior of austenite base lightweight Fe-28Mn-9Al-0.8C steel. Scripta Mater. 63, 1028-1031.

Connétable D, and Maugis P (2008) First principle calculations of the $\mathrm{k}$-Fe3AIC perovskite and iron-aluminium intermetallics. Intermetallics 
16, 345-352.

Gutierrez-Urrutia I, and Raabe D (2012) Multistage strain hardening through dislocation substructure and twinning in a high strength and ductile weight-reduced Fe-Mn-Al-C steel. Acta Mater. 60, 57915802.

Gutierrez-Urrutia I, and Raabe D (2013) Influence of Al content and precipitation state on the mechanical behavior of austenitic high-Mn low-density steels. Scripta Mater. 68, 343-347.

Noh J Y, and Kim H (2011) Density Functional Theory Calculations on K-carbides, (Fe,Mn)3AIC. J. Kor. Phys. Soc. 58, 285-290.

Raabe D, Springer H, Gutierrez-Urrutia I, Rosters F, Bausch M, Seol J B, Koyama M, Choi P P, and Tsuzaki K (2014) Alloy Design, Combinatorial Synthesis, and Microstructure-Property Relations for Low-Density Fe-Mn-Al-C Austenitic Steels. JOM 66, 1845-1856.

Seol J B, Jung J E, Jang Y W, and Park C G (2013) Influence of carbon content on the microstructure, martensitic transformation and mechanical properties in austenite/ $\varepsilon$-martensite dual-phase FeMn-C steels. Acta Mater. 61, 558-578.
Seol J B, Raabe D, Choi P, Lim Y R, and Park C G (2012) Atomic scale effects of alloying, partitioning, solute drag and austempering on the mechanical properties of high-carbon bainitic-austenitic TRIP steels. Acta Mater. 60, 6183-6199.

Seol J B, Raabe D, Choi P, and Park H S (2013) Direct evidence for the formation of ordered carbides in a ferrite-based low-density Fe-MnAl-C alloy studied by transmission electron microscopy and atom probe tomography. Scripta Mater. 68, 348-353.

Springer H, and Raabe D (2012) Rapid alloy prototyping: Compositional and thermo-mechanical high throughput bulk combinatorial design of structural materials based on the example of $30 \mathrm{Mn}-1.2 \mathrm{C}-\mathrm{xAl}$ triplex steels. Acta Mater. 60, 4950-4959.

Yao M J, Dey P, Seol J B, Choi P, Herbig M, Marceau R K W, Hickel T, Neugebauer J, and Raabe D (2016) Combined atom probe tomography and density functional theory investigation of the Al offstoichiometry of k-carbides in an austenitic Fe-Mn-Al-C low density steel. Acta Mater. 106, 229-238. 